\title{
Fast increases in urban sewage inputs to rivers of Indonesia
}

\author{
Djoko Suwarno $\cdot$ Ansje Löhr $\cdot$ Carolien Kroeze $\cdot$ Budi Widianarko
}

Received: 10 October 2013/Accepted: 10 January 2014/Published online: 13 March 2014

(C) The Author(s) 2014. This article is published with open access at Springerlink.com

\begin{abstract}
We present estimates for nitrogen (N) and phosphorus (P) sewage inputs to 19 Indonesian rivers for 1970-2050. Future trends are based on the four scenarios of the Millennium Ecosystem Assessment. Our results indicate a rapid increase in $\mathrm{N}$ and $\mathrm{P}$ pollution from sewage over time. In 1970, N and P inputs to rivers were low because not many households were connected to sewage systems discharging to rivers. Sewage connection is increasing over time. As a result, $\mathrm{N}$ and $\mathrm{P}$ inputs to rivers increase. We calculate that between 2000 and 2050 the $\mathrm{N}$ and $\mathrm{P}$ inputs increase with a factor of 17-40, depending on the scenario. Important determinants of future $\mathrm{N}$ and $\mathrm{P}$ sewage inputs are population, economic growth, urbanization, sewage systems development and wastewater treatment. Our calculations are based on an improved model for $\mathrm{N}$ and $\mathrm{P}$ inputs to rivers, indicating that previous estimates underestimated these inputs considerably.
\end{abstract}

Keywords Nitrogen and phosphorus $\cdot$ Sewage $\cdot$ Nineteen Indonesian rivers $\cdot$ Wastewater treatment $\cdot$ MEA scenarios

D. Suwarno $(\bowtie) \cdot$ A. Löhr $\cdot$ C. Kroeze

Faculty of Management, Science \& Technology, School of Science, Open University, Valkenburgerweg 177, Heerlen, The Netherlands

e-mail:dj.suwarno@gmail.com
A. Löhr
e-mail: ansje.lohr@ou.nl
C. Kroeze
e-mail: carolien.kroeze@ou.nl
D. Suwarno · B. Widianarko

Soegijapranata Catholic University, J1. Pawiyatan Luhur IV/1 Bendan Duwur, Semarang 50234, Central Java, Indonesia

e-mail: widianarko@unika.ac.id

C. Kroeze

Environmental Systems Analysis Group, Wageningen University, P.O. Box 47, 6700 AA Wageningen, The Netherlands 


\section{Introduction}

Water pollution caused by domestic waste is a serious problem in the large cities of Indonesia such as Bandung, Jakarta, Semarang and Surabaya (Ramu 2004). The rivers that flow through these urban areas are polluted often exceeding water quality standards (Lasut et al. 2005). These problems are driven by high population pressure, increased economic activity and waste discarded untreated (Lasut et al. 2008).

Eutrophication is one of the problems in aquatic systems and is caused by increased nutrient availability in rivers, lakes and marine ecosystems. It is largely driven by increased nitrogen $(\mathrm{N})$ and phosphorus (P) availability (Howarth 2008). Human activities causing increased $\mathrm{N}$ and $\mathrm{P}$ inputs to aquatic systems began about a century ago (Galloway et al. 2004; Seitzinger et al. 2006; Boyer et al. 2006; Mulholland et al. 2008). Eutrophication has become a serious threat to water quality (Selman et al. 2008), reducing the biodiversity and ability of aquatic ecosystems to provide valuable ecosystem services. It may reduce biological oxygen demand to below $2 \mathrm{mg} / \mathrm{l}$ (Diaz and Rosenberg 1995).

Several studies report serious events of eutrophication. Studies show dozens observations of eutrophic and hypoxic coastal systems worldwide (Selman et al. 2008), the global inventory observation hypoxic event and the so-called dead zones (Diaz and Rosenberg 2008). These studies indicate that eutrophication is a problem in all coastal seas of the world (Carpenter et al. 1998).

During the past half century, inputs of $\mathrm{N}$ and $\mathrm{P}$ to coastal marine systems have been increasing relatively fast (Billen and Garnier 2007; Howarth 2008; Glibert et al. 2008). These increases in $\mathrm{N}$ inputs are associated with increased population and economic growth, as well as with changes in the human diet, urbanization and the construction of sewerage systems (Seitzinger et al. 2010; Van Drecht et al. 2009). Increases in P inputs to aquatic systems can be explained by increased agricultural inputs as well as sewage inputs, including human feces and urine, and detergents containing P. In Europe P-free detergents have replaced P-based detergents since three decades ago (RPA 2006). In South America, Asia and Africa, animal manure and sewage are often an important anthropogenic cause of eutrophication (Van der Struijk and Kroeze 2010; Yasin et al. 2010).

In many world regions, anthropogenic nutrient inputs to rivers exceed natural sources (Yasin et al. 2010; Yan et al. 2010). During the coming decades, the risk of coastal eutrophication will likely increase in developing countries as a result of expected population growth, economic growth and the development of wastewater treatment systems (Bouwman et al. 2005; Van Drecht et al. 2009; Garnier et al. 2010).

Coastal eutrophication also occurs in Indonesia. Anthropogenic causes of coastal eutrophication in Indonesia include agriculture, human waste and industrial sources (Sunarto 2006). The impact of eutrophication is visible along, for instance, the northern coast of Java, Sumatra and the eastern coast of Jakarta Bay (Latifah 2004). In 2003 until 2010, the Brantas river water quality declined due to N and P (Masrevaniah 2010). Several polluted rivers export excess nutrients to coastal seas. For instance, the Citarum river is polluted with $\mathrm{N}$ and $\mathrm{P}$ from industrial waste, residential sources and agriculture (Garno 2002). Likewise, freshwater reservoirs have experienced water quality problems leading to excessive growth of floating plants (e.g., water hyacinth, Eichhornia crassipes) and fish kills (Hart et al. 2002). These problems do not only pose a threat to aquatic ecosystems, but also interfere with water availability for human consumption and irrigation (Carpenter et al. 1998). Increased $\mathrm{N}$ and $\mathrm{P}$ contents in downstream rivers have been considered a some of the problems (Yuliastuti 2011). Feces and detergents are the largest sources of $\mathrm{N}$ and $\mathrm{P}$ in domestic waste. How $\mathrm{N}$ and $\mathrm{P}$ emissions to the rivers in Indonesia may develop in the future depends on urbanization and developments in sewage systems. 
In this study, we will analyze inputs of nutrients to rivers by means of a quantitative model. We will use the Global NEWS (Nutrient Export from Water Sheds) model (Mayorga et al. 2010; Seitzinger et al. 2010). This model can be used to analyze past and future trends in the export of nutrients to coastal seas in a spatially explicit way.

The Global NEWS models have been developed since the late 1990s (Beusen et al. 2005; Dumont et al. 2005; Harrison et al. 2005a, b; Seitzinger et al. 2006). Early versions of the models calculated the river export of various forms of either $\mathrm{N}, \mathrm{P}$, or carbon (C) as a function of hydrology, basin characteristics, land use and human activities in 6000 watersheds (Seitzinger et al. 2006). These early versions of Global NEWS consisted of a set of models for different forms of nutrients. In the most recent version of Global NEWS, these sub-models have been integrated in a one model interface (Seitzinger et al. 2010; Mayorga et al. 2010). Also silica ( $\mathrm{Si}$ ) is now included in the model. The latest version of the Global NEWS model has been used to analyze past and future trends in nutrient export by rivers for the period 1970-2050 (Seitzinger et al. 2010).

In an earlier study (Suwarno et al. 2013), we compared $\mathrm{N}$ and $\mathrm{P}$ measurements at the mouths of 19 selected rivers in Indonesia with the modeled values from the Global NEWS model. In general, we concluded that the fit is reasonable, considering that the model was not originally developed for Indonesia. For some rivers, the fits are very good, while for others, there is a difference between measured and modeled values. We concluded, therefore, that the Global NEWS model can be used for an analysis of nutrient export by these Indonesian rivers at the regional scale. However, we also concluded that sewage inputs are not well represented in the model for Indonesian rivers.

The purpose of this study is, therefore, to model sewage $\mathrm{N}$ and $\mathrm{P}$ inputs to the 19 selected Indonesian rivers. To this end, we will first summarize the Global NEWS approach to model sewage inputs. Next, we will evaluate this approach on the basis of local information, and finally, we will propose an improved model for sewage inputs to Indonesian rivers.

\section{Materials and methods}

\subsection{Global NEWS and the Millennium Ecosystem Assessment Scenarios}

The Global NEWS model calculates nutrient export from land to sea as a function of hydrology, river basin characteristics and human activities on the land. As explained above, several versions of the Global NEWS model exist. In 2005, Global NEWS-1 submodels were released (Beusen et al. 2005; Dumont et al. 2005; Harrison et al. 2005a, b; Seitzinger et al. 2005). These sub-models calculate the export of different forms of $\mathrm{N}, \mathrm{P}$ and $\mathrm{C}$ for more than 6,000 rivers. A strength of the Global NEWS model is that it can be used for analyses of different nutrients simultaneously, for different years (past and future) and that it can be used for analyses of the sources of nutrients in rivers. This comprehensiveness is one of the main differences with some other global models, that tend to focus on one nutrient, or one time period only (e.g., He et al. 2011).

In 2010, an improved version of Global NEWS (version 2) was released (Beusen et al. 2009; Harrison et al. 2010; Mayorga et al. 2010; Seitzinger et al. 2010). This version of the Global NEWS model calculates river export of dissolved inorganic N, P and C (DIN, DIP and DIC), dissolved organic N, P and C (DON, DOP and DOC), particulate N and P (PN and $\mathrm{PP}$ ) and dissolved silica ( $\mathrm{Si})$. One of the improvements in this version is the modeling of detergent $\mathrm{P}$ as a source of dissolved inorganic $\mathrm{P}$ in rivers (Harrison et al. 2010). In addition, the sub-model for river export of dissolved silica was new in Global NEWS-2 
(Beusen et al. 2009). Moreover, the sub-models were integrated into one modeling environment (Mayorga et al. 2010). And finally, Global NEWS-2 was used to analyze past trends and future scenarios (for the period 1970-2050). The scenarios for the future were based on the Millennium Ecosystem Assessment (MEA) (Alcamo et al. 2005). This required the development of spatially explicit model inputs for diffuse nutrient inputs from agricultural and natural ecosystems (Bouwman et al. 2005), for point sources (sewage) (Van Drecht et al. 2009) and hydrology (Fekete et al. 2010). These model inputs are consistent with the social, economic policy and ecological assumptions in the MEA scenarios (Mayorga et al. 2010). Our scenarios are comparable to nitrogen scenarios developed on the basis of the IPCC SRES scenarios (Bodirski et al. 2012).

Millennium Ecosystem Assessment includes four scenarios for 2030 and 2050: Adapting Mosaic (AM), Global Orchestration (GO), Order from Strength (OS), and TechnoGarden (TG). These scenarios differ with respect to the assumed socioeconomic developments (regionalization or globalization) and the assumed approach toward environmental management (reactive of proactive). AM describes a regionalized world with a proactive approach toward ecosystem management based on simple technologies. It assumes access to good sanitation, but no large increase in sewage connections. Rather it assumes recycling of waste to substitute fertilizer $\mathrm{N}$ and $\mathrm{P}$. GO is a globalized world assuming a reactive approach toward ecosystem problems and investments in infrastructure and education. Access to good sanitation and improved sewage connection is assumed in this scenario between 2000 and 2050. Moreover, wastewater treatment is more advanced in this world. OS describes a regionalized world with small investments in infrastructure. It takes a reactive approach toward ecosystem problems. Connection to sewage systems is comparable to urbanization with good sanitation, water treatment systems and sewage disposal treatment systems will be expanded and replaced by more advanced systems. TG is a globalized scenario assuming a proactive approach toward ecosystem management. It assumes successful environmental technologies to ensure and protect ecosystem services (Alcamo et al. 2005).

\subsection{Sewage in Global NEWS}

The Global NEWS approach to calculate sewage inputs to rivers is described in Mayorga et al. (2010) and Van Drecht et al. (2009) (Table 1). Here, we summarize the approach. Mayorga et al. (2010) describe how river export of $\mathrm{N}$ and $\mathrm{P}$ from sewage to sea is calculated in Global NEWS. Van Drecht et al. (2009) describe how total emissions of N and $\mathrm{P}$ human waste is discharged to surface water and calculated in Global NEWS. Table 1 summarizes the equations. In Global NEWS, the $\mathrm{N}$ and $\mathrm{P}$ inputs from sewage to rivers $\left(E_{\mathrm{sw}}^{\mathrm{N}}\right.$ and $\left.E_{\mathrm{sw}}^{\mathrm{P}}\right)$ are calculated as a function of the human $\mathrm{N}$ and $\mathrm{P}$ emission $\left(E_{\mathrm{hum}}^{\mathrm{N}}\right.$ and $\left.E_{\mathrm{hum}}^{\mathrm{P}}\right)$, the number of people connected to sewage systems $(D)$ and $\mathrm{N}$ and $\mathrm{P}$ removal in waste water treatment $\left(\mathrm{R}^{\mathrm{N}}\right.$ and $\mathrm{R}^{\mathrm{P}}$, respectively).

\subsection{Number of people connected to sewage}

Global NEWS determines the sewer connections based on assumptions about urbanization and technical developments. If the level of urbanization is low, the model assumes little human emission inputs to rivers. For developing countries with a large rural population, the model assumes no sewage systems or waste water treatment. In Southern Asia, only 3-9 \% of the population was connected to sewage systems before the year 2000. For Indonesia, however, they assume no sewage connection at all in the past (Van Drecht et al. 2009). 
Table 1 Summary of the calculation of sewage inputs to rivers as included in the Global NEWS Model (equations following Mayorga et al. 2010; Van Drecht et al. 2009)

\begin{tabular}{ll}
\hline No. & Equations \\
\hline 1. & $E_{\mathrm{sw}}^{\mathrm{N}}=E_{\mathrm{hum}}^{\mathrm{N}} * D *\left(1-R^{\mathrm{N}}\right) * P$ \\
2. & $E_{\mathrm{sw}}^{\mathrm{P}}=\left(E_{\mathrm{hum}}^{\mathrm{P}}+E_{\mathrm{Ldet}}^{\mathrm{P}}+E_{\mathrm{Ddet}}^{\mathrm{P}}\right) * D *\left(1-R^{\mathrm{P}}\right) * P$ \\
3. & $I_{\mathrm{hum}}^{\mathrm{N}}=4+14 *\left[\mathrm{GDP}_{\mathrm{ppp}} / 33000\right]^{0.3}$ \\
4. & $E_{\mathrm{hum}}^{\mathrm{N}}=0.365 * I_{\text {hum }}^{\mathrm{N}}$ \\
5. & $E_{\mathrm{hum}}^{\mathrm{P}}=f_{\mathrm{N}}^{\mathrm{P}} * E_{\mathrm{hum}}^{\mathrm{N}}$ \\
6. & $E_{\mathrm{Ldet}}^{\mathrm{P}}=E_{\mathrm{Ldet}} * f_{\mathrm{Ldet}}^{\mathrm{P}} *\left(1-f_{\mathrm{Ldet}}^{\mathrm{Pfree}}\right)$ \\
7. & $E_{\mathrm{Ldet}}=10-10 *\left[\left(\mathrm{GDP}_{\text {mer }} / 20000\right)-1\right]^{2}$ \\
8. & $f_{\mathrm{Ldet}}^{\mathrm{Prree}}=\mathrm{GDP}_{\mathrm{mer}} / 33000$ \\
\hline
\end{tabular}

Variables and parameters (Unit)

$E_{\mathrm{sw}}^{\mathrm{N}}=\mathrm{N}$ emission to surface water $\left(\mathrm{t}_{\text {year }}{ }^{-1}\right)$

$E_{\text {hum }}^{\mathrm{N}}=$ human $\mathrm{N}$ emission $\left(\mathrm{kg}_{\text {person }}{ }^{-1}\right.$ year $\left.^{-1}\right)$

$D=$ population connected to the public sewerage system (fraction)

$R^{\mathrm{N}}=\mathrm{N}$ removal in the wastewater treatment (fraction)

$E_{\mathrm{sw}}^{\mathrm{P}}=\mathrm{P}$ emission into surface water $\left(\mathrm{kg}_{\text {person }}{ }^{-1}\right.$ year $\left.^{-1}\right)$

$P=$ population in the river basin (thousands)

$E_{\text {hum }}^{\mathrm{P}}=$ human $\mathrm{P}$ emissions $\left(\mathrm{kg}\right.$ person $^{-1}$ year $^{-1}$ )

$E_{\mathrm{Ldet}}^{\mathrm{P}}=\mathrm{P}$ emissions from laundry detergents $\left(\mathrm{kg}\right.$ person $^{-1}$ year $\left.^{-1}\right)$

$E_{\text {Ddet }}^{\mathrm{P}}=\mathrm{P}$ emission from dishwasher detergent $\left(\mathrm{kg}_{\text {person }}{ }^{-1}\right.$ year $\left.^{-1}\right)$

$R^{\mathrm{P}}=\mathrm{P}$ removal in the wastewater treatment (fraction)

$I_{\text {hum }}^{\mathrm{N}}=\mathrm{N}$ protein intake $\left(\mathrm{kg}_{\text {person }}{ }^{-1} \mathrm{day}^{-1}\right)$

$\underset{\left.\text { year }^{-1}\right)}{\mathrm{GDP}_{\text {pp }}}=$ gross national domestic product per capita at purchasing power parity (1995 U.S.\$ person ${ }^{-1}$ $\mathrm{GDP}_{\text {mer }}=$ gross national domestic product per capita at market exchange rate (1995 U.S.\$ person $^{-1}$ year $^{-1}$ ) $f_{\mathrm{N}}^{\mathrm{P}}=$ ratio between the emissions of human $\mathrm{P}$ to $\mathrm{N}$

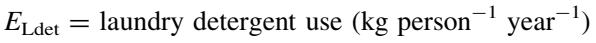

$f_{\text {Ldet }}^{\mathrm{P}}=\mathrm{P}$ content of laundry detergent $(\mathrm{kg} / \mathrm{kg})$

$f_{\mathrm{Ldet}}^{\mathrm{Pfree}}=$ fraction of laundry detergent that is P-free (fraction)

In Global NEWS it is, therefore, assumed that in 1970 and 2000, no Indonesian people were connected to sewage systems $(D=0)$. In the future scenarios, the number of people connected to sewage systems is assumed to be increasing, but not in all rivers. In 2050, Global NEWS assumes that in most Indonesian river basins, sewage connection is still negligible $(D=0)$. Moreover, the model ignores that $20 \%$ of the population of Indonesia are defecating directly in the waters of the river (Van Drecht et al. 2009).

\section{$2.4 \mathrm{~N}$ and $\mathrm{P}$ removal in wastewater treatment}

Van Drecht et al. (2009) distinguish between four types of wastewater treatment with different treatment efficiencies, expressed by $\mathrm{N}$ and $\mathrm{P}$ removal fraction as in Eqs. (1) and 
Table 2 Sewage N and P inputs to the Solo river in 2030 (Global Orchestration Scenario) as calculated in Global NEWS, following Van Drecht et al. 2009

\begin{tabular}{|c|c|c|c|}
\hline Variable & Value & Unit & Remark \\
\hline$E_{\mathrm{sw}}^{\mathrm{N}}$ & 27,672 & t year $^{-1}$ & Output of Eq. 1 (Table 1) \\
\hline$E_{\mathrm{hum}}^{\mathrm{N}}$ & 5.22 & $\mathrm{~kg}_{\text {person }}{ }^{-1}$ year $^{-1}$ & Output of Eq. 4 (Table 1) \\
\hline$D$ & 0.39 & Fraction & $\begin{array}{l}\text { Global NEWS Run } 5 \text { model assumption } \\
\text { (Mayorga et al. 2010) }\end{array}$ \\
\hline$E_{\mathrm{sw}}^{\mathrm{P}}$ & 5,743 & t year ye $^{-1}$ & Output of Eq. 2 (Table 1) \\
\hline$E_{\text {hum }}^{\mathrm{P}}$ & 0.87 & $\mathrm{~kg}_{\text {person }}{ }^{-1}$ year $^{-1}$ & Output of Eq. 5 (Table 1) \\
\hline$E_{\mathrm{Ldet}}^{\mathrm{P}}$ & 0.18 & $\mathrm{~kg}_{\text {person }}{ }^{-1}$ year $^{-1}$ & Output of Eq. 6 (Table 1) \\
\hline$E_{\text {Ddet }}^{\mathrm{P}}$ & 0 & $\mathrm{~kg}_{\text {person }}{ }^{-1}$ year $^{-1}$ & $\begin{array}{l}\text { No dishwashers assumed in the Solo } \\
\text { basin in Global NEWS }\end{array}$ \\
\hline$R^{\mathrm{N}}$ & 0.05 & Fraction & $\begin{array}{l}\text { Global NEWS Run } 5 \text { model assumption } \\
\text { (Mayorga et al. (2010) }\end{array}$ \\
\hline$R^{\mathrm{P}}$ & 0.05 & Fraction & $\begin{array}{l}\text { Global NEWS Run } 5 \text { model assumption } \\
\text { (Mayorga et al. 2010) }\end{array}$ \\
\hline$I_{\text {hum }}^{\mathrm{N}}$ & 14.3 & g person ${ }^{-1}$ day $^{-1}$ & Output of Eq. 3 (Table 1) \\
\hline $\mathrm{GDP}_{\text {mer }}$ & 6,090 & US\$ in 1995 & $\begin{array}{l}\text { Global NEWS Run } 5 \text { model assumption } \\
\text { (Mayorga et al. 2010) }\end{array}$ \\
\hline $\mathrm{GDP}_{\mathrm{PPP}}$ & 11,852 & US\$ in 1995 & $\begin{array}{l}\text { Global NEWS Run } 5 \text { model assumption } \\
\text { (Mayorga et al. 2010) }\end{array}$ \\
\hline$f_{\mathrm{N}}^{\mathrm{P}}$ & $1 / 6$ & Fraction & Van Drecht et al. (2009) \\
\hline $\mathrm{E}_{\text {Ldet }}$ & 5.2 & $\mathrm{~kg}_{\text {person }}{ }^{-1}$ year $^{-1}$ & Output of Eq. 7 (Table 1) \\
\hline$f_{\text {Ldet }}^{P}$ & 0.12 & $\mathrm{~kg} / \mathrm{kg}$ & Van Drecht et al. (2009) \\
\hline$f_{\text {Ldet }}^{\text {Pfree }}$ & 0.36 & Fraction & Output of Eq. 8 (Table 1) \\
\hline
\end{tabular}

See Table 1 for explanation of parameter and variable names

(2). For N-specific removal efficiencies (R) are based on four types of waste water treatment: no treatment $(0 \%$ removal), mechanical (primary) treatment (10\% removal), biological (secondary) treatment (35\% removal) and advanced (tertiary) treatment (80\% removal) (Bouwman et al. 2005).

The overall $\mathrm{N}$ and $\mathrm{P}$ removal fractions are low in most developing countries in the period 1970-2000. These removal fractions are assumed to remain low in the future in most developing countries, based on the assumption that advanced biological waste water treatment will not be applied widespread. The maximum removal fractions for developing countries are in Global NEWS typically below $35 \%$ throughout the simulation period (1970-2050) and often not even higher than $10 \%$. In other world regions, these removal rates can be up to $80 \%$ for $\mathrm{N}$ and $90 \%$ for $\mathrm{P}$, based on the current processing technology. In many industrialized countries, the nutrient removal fraction has substantially increased over the past decade because of the optimized management. In addition, P-free detergents are increasingly used for washing as GDP increases (Eq. 8).

For rivers in Indonesia, the Global NEWS model assumes relatively low $\mathrm{N}$ and $\mathrm{P}$ removal in waste water treatment (5\% in 2000, increasing up to $12 \%$ in 2050).

\subsection{Example: Solo river}

We take the Solo river as an example to illustrate how the Global NEWS model calculates sewage $\mathrm{N}$ and $\mathrm{P}$ inputs to rivers using the equations of Van Drecht et al. (2009) (Tables 2). 
We take the year 2030 and the scenario GO as an example. In this scenario, the human $\mathrm{N}$ and $\mathrm{P}$ emission is $2 \mathrm{~kg}_{\text {person }}{ }^{-1}$ year $^{-1}$ and $0.5 \mathrm{~kg}_{\text {person }}{ }^{-1}$ year $^{-1} ; 39 \%$ of the people are assumed to be connected to sewage systems, and the $\mathrm{N}$ and $\mathrm{P}$ removal are $13.7 \%$ and $16.2 \%$. As a result, the total $\mathrm{N}$ and $\mathrm{P}$ export by the Solo river amounts to 29,907 and

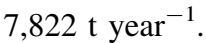

\section{Results}

\subsection{Evaluation of Global NEWS approach for sewage in Indonesia}

\subsubsection{Strengths of Global NEWS}

The Global NEWS model has many strengths. It is the first global, spatially explicit model of nutrient export from land to sea that includes multiple nutrients in manifold forms. It is a complete and comprehensive model which has been used to analyze past and future trends.

The Global NEWS model has been validated on the global scale. It can explain 60-90\% of the variation in observed nutrient export by world rivers (Mayorga et al. 2010). It has also been validated at continental and regional scales, indicating that the model is applicable at multiple levels (Qu and Kroeze 2010; Van der Struijk and Kroeze 2010; Yasin et al. 2010; Yan et al. 2010; Qu and Kroeze 2012; Scheren et al. 2004; Seitzinger et al. 2002). This makes it a powerful tool to analyze eutrophication in coastal areas of data-poor regions.

Other strengths of this model are that it can be used to analyze N, P, C and Si fluxes in various forms simultaneously. It has proven particularly useful for analyses in data-poor regions (Scheren et al. 2004). Moreover, it provides insight in the causes of increased river nutrient export.

The Global NEWS approach also includes an indicator for coastal eutrophication potential (ICEP) (Garnier et al. 2010). This is an indicator for the environmental and social implications of excessive nutrients in coastal waters. It is based on the ratio of N/P/Si, which is an indicator for the occurrence of harmful algal blooms. The structure of the Global NEWS model makes it possible to analyze trends in ICEP over time and to relate these trends to trends in human activities on the land.

\subsection{Suggestions for improvement for Indonesia}

Global NEWS was not specifically developed for Indonesia, but based on global assumptions on sewage inputs to rivers. We propose a number of improvements in the model and the model parameters (Table 3) based on the available data from local studies.

\subsubsection{Fraction of people connected to sewage}

As indicated above, Global NEWS assumes that the number of people connected to sewage $(D)$ is 0 in 1970 and 2000. In future years, the fraction of people connected to sewage is expected to increase to $20-80 \%$ of the total population. In Global NEWS, these increases are based on general assumptions for Southeast Asia and Oceania. Here, we used estimates that are more specific for Indonesia, based on expert judgment (Coordinating Ministry for 
Table 3 Model assumptions in the improved model for sewage (see text for references)

\begin{tabular}{|c|c|c|c|c|c|c|c|c|c|c|}
\hline \multirow[t]{2}{*}{ Variable } & \multirow[t]{2}{*}{1970} & \multirow[t]{2}{*}{2000} & \multicolumn{4}{|l|}{2030} & \multicolumn{4}{|l|}{2050} \\
\hline & & & AM & GO & OS & TG & $\mathrm{AM}$ & GO & OS & $\mathrm{TG}$ \\
\hline D (fraction) & $0 *$ & $0^{*}$ & $0.35 * *$ & $0.40 * *$ & $0.35 * *$ & $0.40 * *$ & $0.60 * *$ & $0.70 * *$ & $0.60 * *$ & $0.70 * *$ \\
\hline $\begin{array}{l}R^{\mathrm{N}} \text { and } R^{\mathrm{P}} \\
\quad \text { (fraction) }\end{array}$ & $0 *$ & $0 *$ & 0.03 & 0.03 & 0.03 & 0.03 & 0.10 & 0.04 & 0.04 & 0.40 \\
\hline$f_{\text {Ldet }}^{P}(\mathrm{~kg} / \mathrm{kg})$ & 0.18 & 0.18 & 0.18 & 0.18 & 0.18 & 0.18 & 0.18 & 0.18 & 0.18 & 0.18 \\
\hline$f_{\text {Ldet }}^{\text {Pfree }}$ (fraction) & $0 *$ & $0 *$ & 0.65 & 0.50 & 0.50 & 0.75 & 0.80 & 0.50 & 0.50 & 0.80 \\
\hline $\begin{array}{l}\text { Urban } \\
\text { population } \\
\text { (fraction) }\end{array}$ & 0.17 & 0.42 & $*$ & $*$ & $*$ & $*$ & $*$ & $*$ & $*$ & $*$ \\
\hline$E_{\mathrm{dir}}^{\mathrm{N}} * * *$ & \multicolumn{10}{|c|}{ For 1970 and 2000: $E_{\mathrm{dir}}^{\mathrm{N}}=$ urban population in basin $* 0.2 * E_{\mathrm{hum}}^{\mathrm{N}}$} \\
\hline$E_{\mathrm{dir}}^{\mathrm{P}} * * *$ & \multirow{2}{*}{\multicolumn{10}{|c|}{$\begin{array}{l}\text { For } 1970 \text { and 2000: } E_{\mathrm{dir}}^{\mathrm{P}}=\text { urban population in } \\
\text { for all scenarios: } 1.6 * E_{\mathrm{hum}}^{\mathrm{N}} \text { Global NEWS }\end{array}$}} \\
\hline$E_{\mathrm{hum}}^{\mathrm{N}}$ & & & & & & & & & & \\
\hline$E_{\text {hum }}^{\mathrm{P}}$ & \multicolumn{10}{|c|}{ for all scenarios: $1.6 * E_{\mathrm{hum}}^{\mathrm{P}}$ Global NEWS } \\
\hline
\end{tabular}

* As in Global NEWS

** Applied to urban population only

$* * * E_{\mathrm{dir}}^{\mathrm{N}}$ and $E_{\mathrm{dir}}^{\mathrm{P}}=$ direct input of human waste in rivers (to be added to $E_{\mathrm{sw}}^{\mathrm{N}}$ and $E_{\mathrm{sw}}^{\mathrm{P}}$ )

Economic Affairs 2011). These assumptions are that sewage connection increases to $60-70 \%$ of the urban population in 2050 .

\subsubsection{Human $N$ and $P$ inputs to rivers}

In Global NEWS, there are only two possibilities: Either people are connected to sewage systems discharging to rivers or human waste is not discharged to rivers (Galloway et al. 2004). In reality, however, nearly $20 \%$ of the Indonesian population is defecating directly into rivers in 1970. This input of $\mathrm{N}$ and $\mathrm{P}$ in rivers is ignored in Global NEWS. Here, we include it for 1970 and 2000. We assume that within a decade, this type of waste disposal will disappear, in line with current policy plans to connect people to sewage systems with waste water treatment (Dwipayanti and Purnama 2010).

In addition, local studies indicate that the estimates of human waste production in terms of $\mathrm{N}$ and $\mathrm{P}$ emissions in Global NEWS ( $E_{\mathrm{hum}}^{\mathrm{N}}$ and $E_{\mathrm{hum}}^{\mathrm{P}}$ ) are too low for Indonesia (see e.g., Rahway 2002). The Global NEWS estimates are based on generic relations between human waste production and GDP. For Indonesia, this generic approach implies emission levels that are relatively low. Indonesian studies, however, indicate that the actual $\mathrm{N}$ and $\mathrm{P}$ emission by humans is $60 \%$ higher than the Global NEWS estimate (Rahway 2002). We therefore increase the Global NEWS estimate by a factor of 1.6 for all years and scenarios.

\subsection{3 $N$ and $P$ removal in waste water treatment}

The Global NEWS model assumes $5 \% \mathrm{~N}$ and P removal in 1970 and 2000, increasing to $12 \%$ in the future. Local studies indicate that this increase may be quite optimistic for Indonesia in the near future (Van der Struijk and Kroeze 2010). However, compared to many other countries, $12 \%$ is very low. It is technically possible to remove larger amounts of $\mathrm{N}$ and $\mathrm{P}$ from wastewater. Even though one may not expect fast improvement in waste water treatment in Indonesia during the coming decades, we use higher removal 
percentages in some scenarios assuming proactive environmental management, as indicated in Table 3 (up to $40 \%$ removal in TG). We consider this feasible by 2050 , since removal percentages are still far below what is currently technically possible.

\subsubsection{Fraction of $P$ in detergents and the use of $P$-free detergents}

The Global NEWS model assumes that detergents contain $12 \% \mathrm{P}$. Local studies for Indonesia indicate that the P content of detergents is $18 \%$ (Standard 2006). We therefore use this higher percentage in the calculations.

\subsubsection{Urban population}

The Global NEWS assumes that the Indonesia urban population in 1970 and 2000 is zero. In Indonesian studies, urban population in 1970 and 2000 were $17 \%$ and $42 \%$ (Kamaluddin 2004). For 2030 and 2050, we use the Global NEWS projections.

\section{Discussion}

\subsection{Sewage $\mathrm{N}$ and $\mathrm{P}$ inputs to rivers in Indonesia}

We modeled $\mathrm{N}$ and $\mathrm{P}$ inputs to Indonesian rivers for the period 1970-2050 (following Table 3) and compared our results to estimates following the original approach (Table 1). Tables 4, 5, 6 and Figs. 1 and 2 summarize the results for the 19 selected Indonesian rivers. These 19 rivers are the same rivers as we used in an earlier analysis using Global NEWS (Suwarno et al. 2013). Our results are in all cases higher than the Global NEWS estimates (see Tables 4, 5, 6).

For 1970 and 2000, our estimates of sewage $\mathrm{N}$ and $\mathrm{P}$ inputs to rivers are higher than the Global NEWS approach. In Global NEWS, sewage connection is assumed zero in these years, implying no sewage $\mathrm{N}$ and $\mathrm{P}$ inputs to rivers. We, however, take into account that $20 \%$ of the urban population defecate directly into rivers. This results in $\mathrm{N}$ inputs to rivers of $3.1 \mathrm{kt} \mathrm{year}^{-1}$ (1970) and $16.8 \mathrm{kt} \mathrm{year}^{-1}$ (2000) (Fig. 1). Inputs of P are estimated at $0.5 \mathrm{kt} \mathrm{year}^{-1}$ in 1970 and $2.8 \mathrm{kt} \mathrm{year}^{-1}$ in 2000 (Fig. 2).

In all scenarios for the future, our estimates of sewage $\mathrm{N}$ and $\mathrm{P}$ inputs to rivers are higher than those based on Global NEWS (Figs. 1, 2). Our estimates are 45-600\% higher than the Global NEWS estimates. These differences are the net effect of our assumptions summarized in Table 3 . They can, however, be largely explained by our assumption that in 2030 and 2050 a considerably larger fraction of the urban population is connected to sewage. The Global NEWS assumption that in most basins no sewage connection exists is resulting in a large underestimation of realistic $\mathrm{N}$ and $\mathrm{P}$ inputs to aquatic systems. These differences are large and indicate that the original Global NEWS model underestimates sewage as a source of coastal eutrophication in countries like Indonesia. The differences are particularly large in scenarios Adapting Mosaic (N) and Global Orchestration (P). The most important reason for the underestimation of Global NEWS is that Global NEWS assumes zero sewage connection in many Indonesian basins, while local studies indicate that this is not according to reality. Another reason for differences between this study and Global NEWS for past years is the estimate for direct defecation into rivers (Fig. 3). 


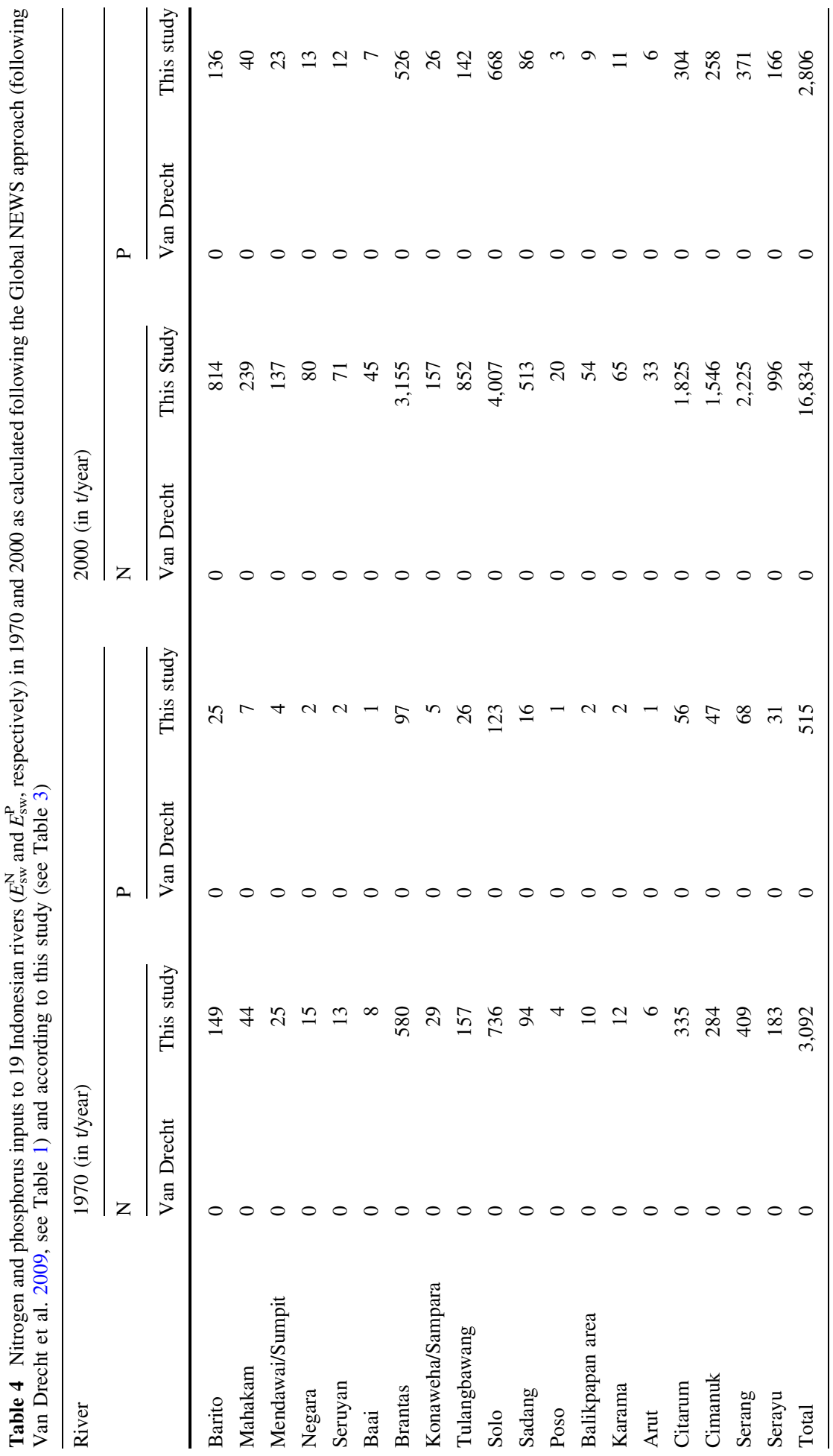




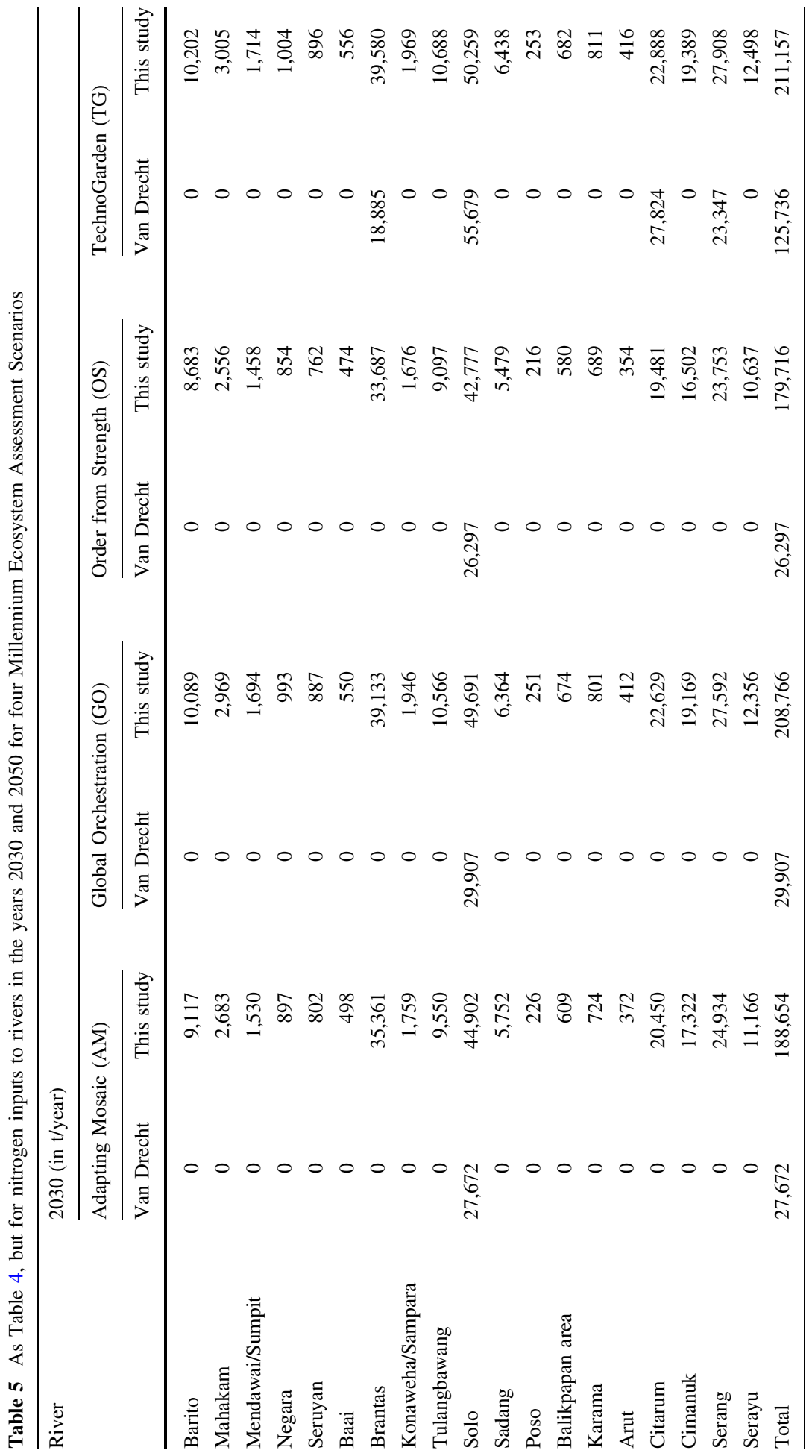




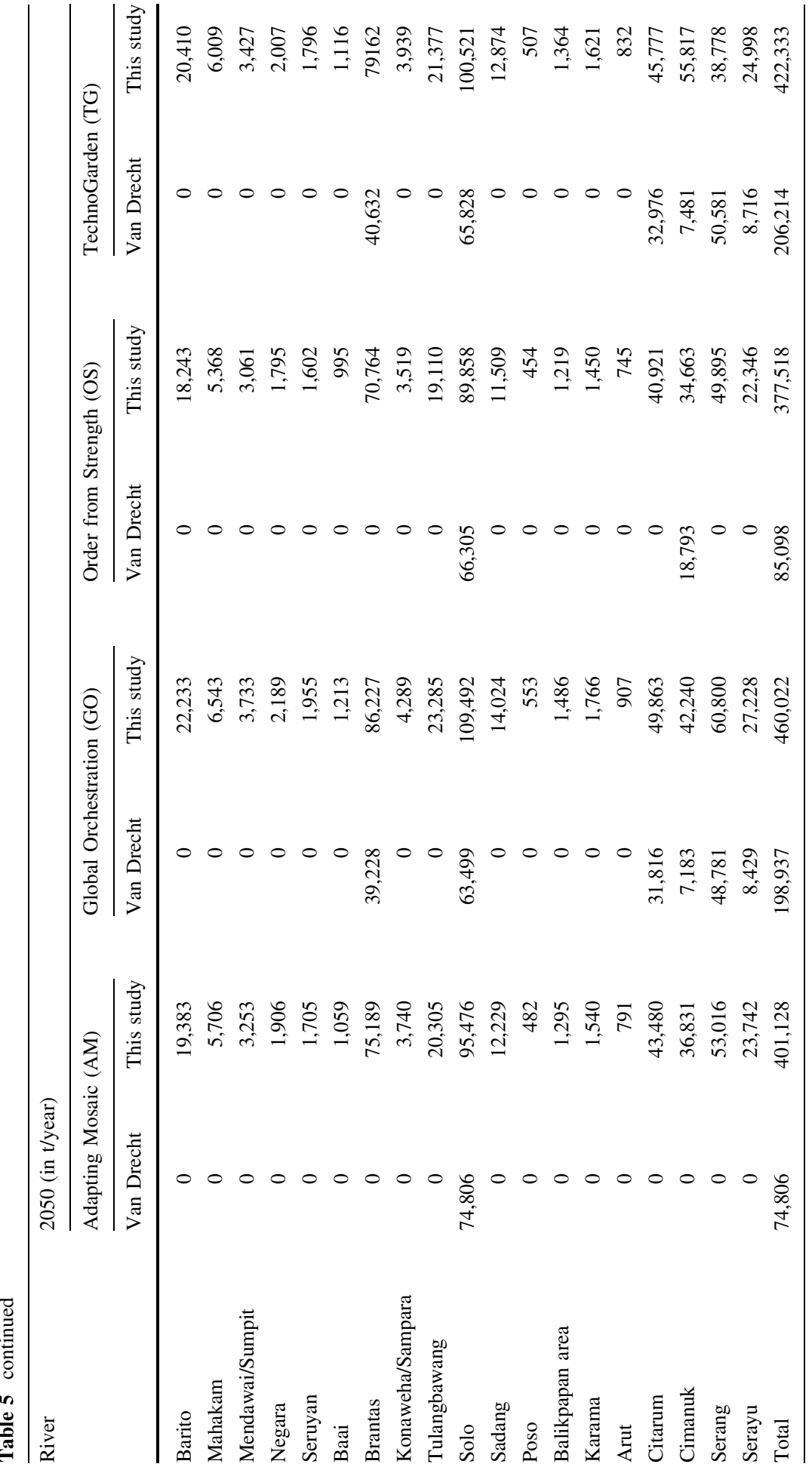




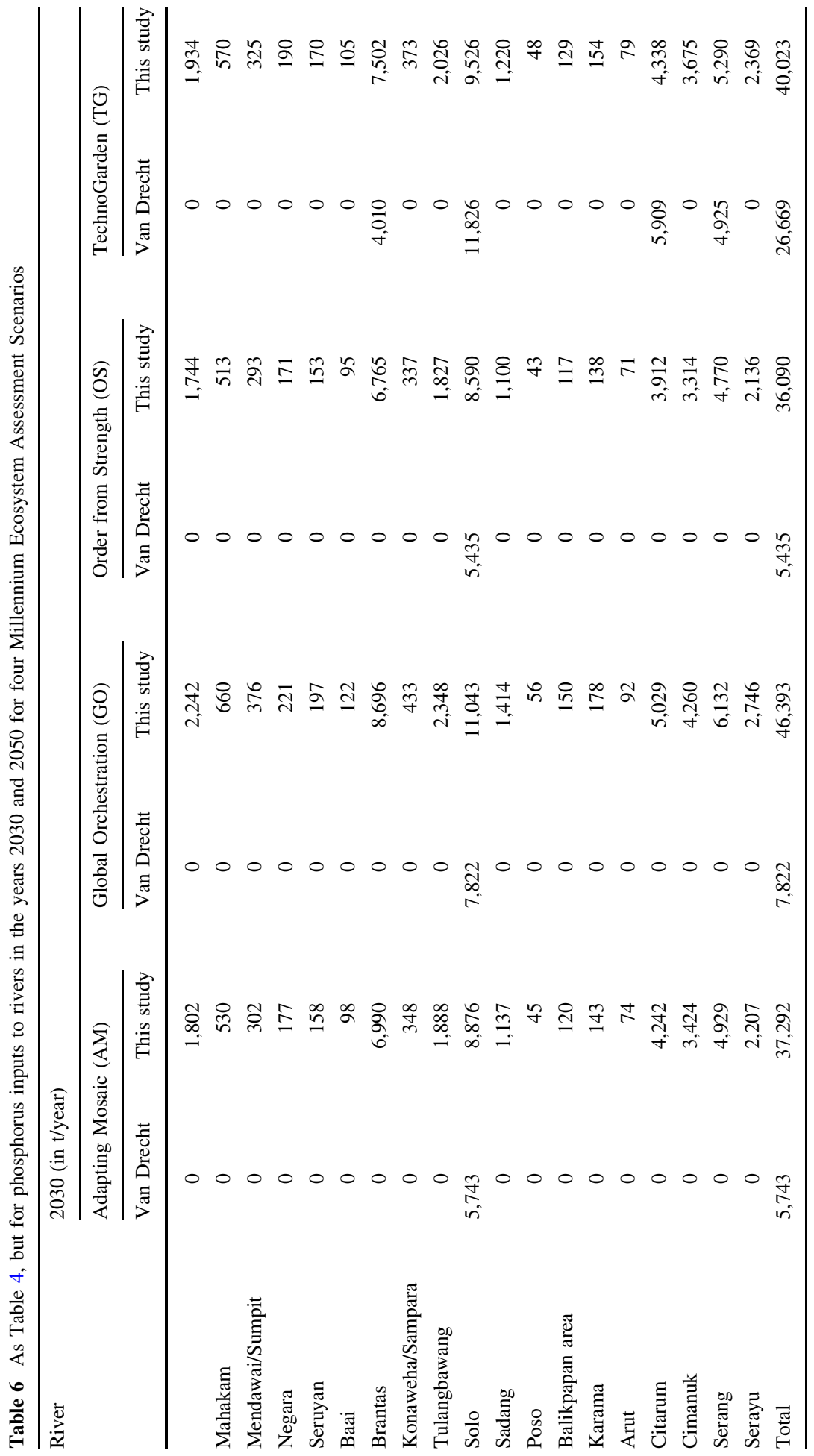




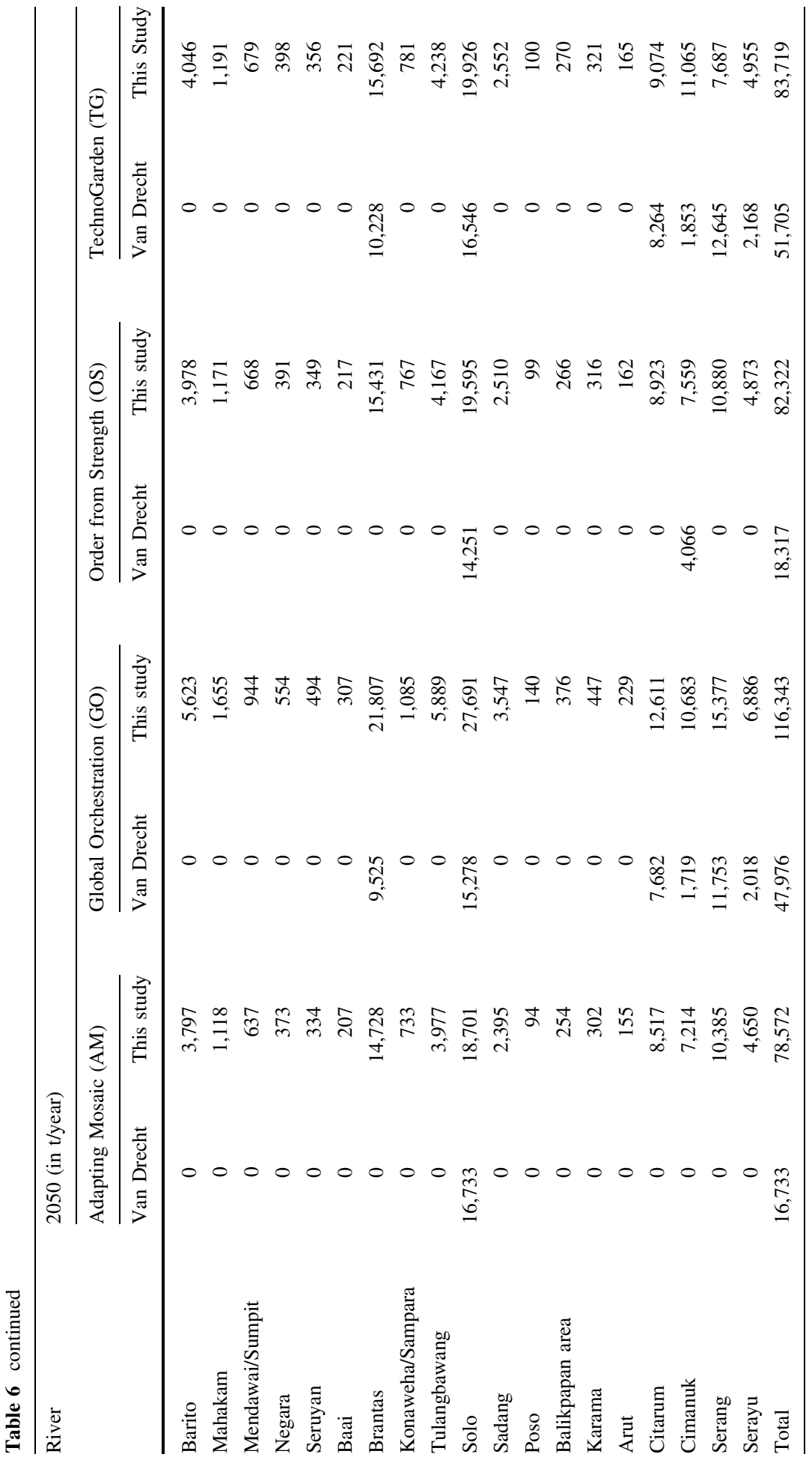




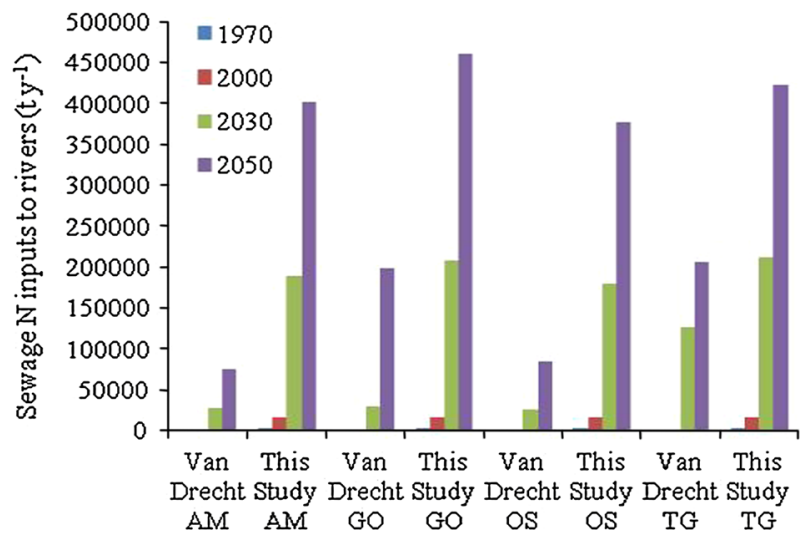

Fig. 1 Nitrogen inputs $\left(E_{s w}^{N}\right)$ to 19 Indonesian rivers in 1970, 2000, 2030 and 2050 as calculated following the Global NEWS approach (following Van Drecht et al. 2009, see Table 1) and according to this study (see Table 3). Results for 2030 and 2050 are for four Millennium Ecosystem Assessment Scenarios (AM, GO, OS, TG, see Table 5)

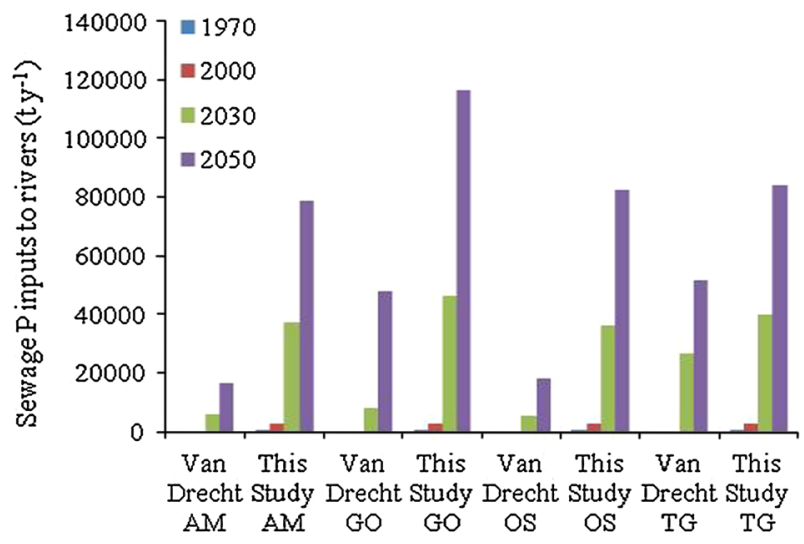

Fig. 2 As Fig. 1, but for phosphorus (see Table 6)

We estimate that total $\mathrm{N}$ and $\mathrm{P}$ emissions from sewage to the 19 Indonesian rivers increase over time. Between 1970 and 2000, N and P inputs increase by more than a factor 4. Between 2000 and 2030, sewage $\mathrm{N}$ and $\mathrm{P}$ inputs to river may increase by a factor of 10-12 for $\mathrm{N}$ and 12-16 for P. By 2050, these inputs have increased by a factor of 17-26 for $\mathrm{N}$ and 20-40 for $\mathrm{P}$ relative to the year 2000. These increasing trends can be largely explained by improved sewage connection. Clearly, the improvement in waste water treatment, as assumed in the TG scenario (40\% $\mathrm{N}$ and $\mathrm{P}$ removal), cannot avoid an increase in sewage inputs to rivers if the sewage connection is as fast as we assume. There is a large difference between the scenarios. Highest increases are calculated for scenario GO and lowest for scenario TechnoGarden. This is in line with the underlying assumptions of the scenarios. GO assumes a globalized world with a focus on economic growth and a reactive approach toward environmental management. TechnoGarden, on the other hand, assumes a proactive approach toward environmental management with high-tech solutions; it assumes relatively effective waste water treatment in Indonesia. It should be noted that 

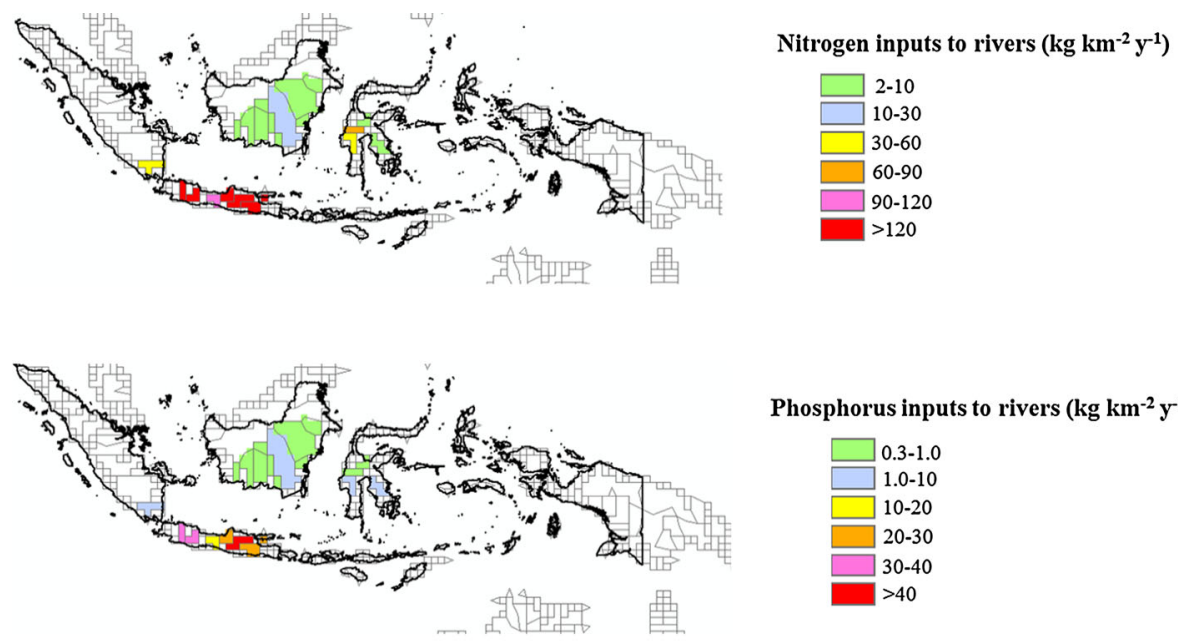

Phosphorus inputs to rivers $\left(\mathrm{kg} \mathrm{km}^{-2} \mathrm{y}^{-1}\right)$

National boundary

River basin boundary

Fig. 3 Nitrogen and Phosphorus inputs to 19 Indonesian rivers in $2000\left(E_{\mathrm{sw}}^{\mathrm{N}}\right.$ and $E_{\mathrm{sw}}^{\mathrm{P}}$ in $\mathrm{kg} \mathrm{km}^{-2}$ year $\left.^{-1}\right)$. Calculated following the Global NEWS approach (Table 1)

our scenarios do not include environmental management options that are specifically focused on nutrient use efficiency. For further analyses, it would be interesting to analyze the potential effect of nutrient use efficiency on eutrophication. A recent study for China indicates the potential environmental impact of such improvements (Fischer et al. 2010).

\section{2 $\mathrm{N}$ and $\mathrm{P}$ removal in waste water treatment}

We assume relatively low $\mathrm{N}$ and $\mathrm{P}$ removal in wastewater treatment compared to many other countries, even though our assumptions may be considered optimistic for Indonesia. This is associated with the costs, energy requirement and skilled labor needed to operate and maintain waste water treatment systems. It seems unrealistic to assume that such expenses will be made in the coming decades in Indonesia. Therefore, we assume low removal of $\mathrm{N}$ and $\mathrm{P}$.

\section{3 $\mathrm{P}$ in detergent and the use of P-free detergents}

The Global NEWS model assumes that detergents contain $12 \% \mathrm{P}$ in the past, but after 2000 , P-based detergents have replaced by P-free detergents. In Indonesia, the content of $\mathrm{P}$ in detergents is higher than Global NEWS namely $18 \%$ in the past. The condition is still applicable until now, so we study assumptions P-based detergent remains the same in the future.

\section{Conclusions}

We evaluated and improved the Global NEWS model for calculating sewage $\mathrm{N}$ and $\mathrm{P}$ inputs to Indonesian rivers. To this end, we suggested several improvements in the model 
and applied the improved model to 19 selected Indonesian rivers. Our estimates are considerably higher than the original Global NEWS estimates based on Van Drecht et al. (2009) We conclude that the Global NEWS assumption that prior to 2000 there was no sewage inputs to Indonesian rivers is incorrect. For future years, our estimates are up to a factor of 6 higher than those in Global NEWS.

Our results indicate that $\mathrm{N}$ and $\mathrm{P}$ inputs from sewage to Indonesian rivers were low in 2000 and before, but may increase very fast during the coming decades. Prior to 2000, human waste inputs to rivers only included direct inputs and no inputs to sewage systems. Between 2000 and 2050, sewage $\mathrm{N}$ and $\mathrm{P}$ inputs to rivers are projected to increase by factors of 20-40, as a result of an increasing number of people connected to sewage systems.

There are at least three reasons for this rapid increase in sewage $\mathrm{N}$ and $\mathrm{P}$ pollution over time. The first is the fast increase in the number of people connected to the sewage system. In past years, human waste was not discharged to rivers through sewage systems because the waste was collected and processed in septic tanks (on-site). Connecting people to the sewage systems is an important factor in Eqs. 1 and 2 of Van Drecht et al. (2009) (Table 1). Second, we assume relatively low $\mathrm{N}$ and $\mathrm{P}$ removal in wastewater treatment compared to many other countries, even though our assumptions may be considered optimistic for Indonesia. Third, we assume an increased use of P-containing detergents in Indonesia in the coming decades. Dishwashers, on the other hand, are assumed to be not an important source of $\mathrm{N}$ and $\mathrm{P}$ in the rivers of Indonesia.

Our results indicate that optimistic assumptions about waste water treatment cannot avoid increase in $\mathrm{N}$ and $\mathrm{P}$ inputs from sewage because of sewage system development. This may hold for more developing countries where policies are focusing on improving living standards by realizing sewage systems. There are, however, ways to avoid some of the projected increase in $\mathrm{N}$ and $\mathrm{P}$ sewage inputs. Future sewage inputs to rivers can be reduced in several ways. For instance, waste water treatment may be combined with biogas production, in which feces can be processed to biogas. The remaining product may be used as fertilizer.

Our study indicates that even though the Global NEWS model has proven to be applicable to multiple scales, it is useful to evaluate the Global NEWS estimates based on local information. Our evaluation of sewage as a source of river pollution in Indonesia shows that the model underestimates point sources of nutrients in rivers. Indonesia may not be unique in this sense. Our study may, therefore, serve as an example for other developing world regions.

Acknowledgments This research was conducted as part of a $\mathrm{PhD}$ study supported by the School of Science of the Open University of the Netherlands and Soegijapranata Catholic University, Semarang, Indonesia. This study was performed as one of the PhD studies in the SENSE Research School. The authors would like to thank Serge Stalpers and Maryna Strokal for their help with data analysis.

Open Access This article is distributed under the terms of the Creative Commons Attribution License which permits any use, distribution, and reproduction in any medium, provided the original author(s) and the source are credited.

\section{References}

Alcamo, J., van Vuuren, D., \& Cramer, W. (2005). Changes in ecosystem services and their drivers across the scenarios. In B. T Sinh et al. (Ed.), Ecosystems and human well-being Chapter 9 (pp. 97-373). Washington: Island Press.

Beusen, A. H. W., Dekkers, A. L. M., Bouwman, A. F., Ludwig, W., \& Harrison, J. A. (2005). Estimation of global river transport of sediments and associated particulate C, N, and P. Global Biogeochemical Cycles, 19, doi: 10.1029/2005GB002453. 
Beusen, A. H. W., Bouwman A. F., Durr, H. H., Dekkers, A. L. M., \& Hartmann, J. (2009). Global patterns of dissolved silica export to the coastal zone: Results from a spatially explicit global model. Global Biogeochemical Cycles, 23. doi: 10.1029/2008GB003281.

Billen, G., \& Garnier, J. (2007). River basin nutrient delivery to the coastal sea: Assessing its potential to sustain new production of non-siliceous algae. Marine Chemistry, 106, 148-160.

Bodirski, B. L., Popp, A., Weindl, I., Dietrich, J. P., Rolinski, S., Scheiffele, L., et al. (2012). $\mathrm{N}_{2} \mathrm{O}$ emissions from the global agricultural nitrogen cycle-Current state and future scenarios. Biogeosciences, 9(4169-4197), 2012.

Bouwman, A. F., Van Drecht, G., Knoop, J. M., Beusen, A. H. W., \& Meinardi, C. R. (2005). Exploring changes in river nitrogen export to the world's oceans. Global Biogeochemical Cycles, 19, 1-14.

Boyer, E. W., Howarth, R. W., Galloway, J. N., Dentener, F. J., Green, P. A., \& Vörösmarty, C. J. (2006). Riverine nitrogen export from the continents to the coasts. Global Biogeochemical Cycles, 20. doi: 10. 1029/2005GB002537.

Carpenter, S. R., Caraco, N. F., Correll, D. L., Howarth, R. W., Sharpley, A. N., \& Smith, V. H. (1998). Nonpoint pollution of surface waters with phosphorus and nitrogen. Ecological Applications, 8, 559-568.

Coordinating Ministry for Economic Affairs RoI. (2011). Masterplan for Acceleration and Expansion of Indonesia Economic Development 2011-2025. In C. M. F. E. Deputy Minister for Coordinating Infrastructure and Regional Development (Ed.), (pp. 15-17). Jakarta.

Diaz, R. J., \& Rosenberg, R. (1995). Marine benthic hypoxia: A review of its Ecological effects and the behavioural responses of benthic macro fauna. Oceanography and Marine Biology Annual Review, 33, 245-303.

Diaz, R. J., \& Rosenberg, R. (2008). Spreading dead zones and consequences for marine ecosystems. Science, 321(5891), 926-929.

Dumont, E., Harrison, J. A., Kroeze, C., Bakker, E. J., \& Seitzinger, S. P. (2005). Global distribution and sources of dissolved inorganic nitrogen export to the coastal zone: Results from a spatially explicit, global model. Global Biogeochemical Cycles, 19, 1-14. doi:10.1029/2005GB002488.

Dwipayanti, N. M. U., \& Purnama, I. G. H. (2010). Sewage treatment in settlements slums and solid Denpasar: How to optimize access. In the national seminar on urbanization and health. Studies Program of Community Health Sciences, Faculty of Medicine, Udayana University, Denpasar.

Fekete, B.M., Wisser, D., Kroeze, C., Mayorga, E., Bouwman, L., Wollheim, W. M., et al. (2010). Millennium Ecosystem Assessment scenario drivers (1970-2050), climate and hydrological alterations. Global Biogeochemical Cycles, 24. doi:10.1029/2009GB003593.

Fischer, G., Winiwarter, W., Ermolieva, T., Cao, G.-Y., Qui, H., Klimont, Z., et al. (2010). Integrated modeling framework for assessment and mitigation of nitrogen pollution from agriculture: Concept and case study for China. Agriculture, Ecosystems \& Environment, 136, 116-124.

Galloway, J. N., Dentener, F. J., Capone, D. G., Boyer, E. W., Howarth, R. W., Seitzinger, S. P., et al. (2004). Nitrogen cycles: Past, present, and future. Biogeochemistry, 70, 153-226.

Garnier, J., Beusen, A. H. W., Thieu, V., Billen, G., \& Bouwman, A. F. (2010). N, P, Si Nutrient export ratios and ecological consequences in coastal seas evaluated by the ICEP approach. Global Biogeochemical Cycles, 24. doi:10.1029/2009GB003583.

Garno, Y. S. (2002). Burden of aquaculture waste pollution and eutrophication in the waters of the reservoir watershed Ciliwung. Journal of Environmental Technology, 3(2), 112-120.

Glibert, P. M., Mayorga, E., \& Seitzinger, S. P. (2008). Prorocentrum minimum tracks anthropogenic nitrogen and phosphorus inputs on a global basis: Application of spatially explicit nutrient export models. Harmful Algae, 8, 33-38. doi:10.1016/j.hal.2008.08.023.

Harrison, J. A., Bouwman, A. F., Mayorga, E., \& Seitzinger, S. (2010). Magnitudes and sources of dissolved inorganic phosphorus inputs to surface fresh waters and the coastal zone: A New Global Model. Global Biogeochemical Cycles, 24. doi:10.1029/2009GB003590.

Harrison, J. A., Caraco, N., \& Seitzinger, S. P. (2005a). Global patterns and sources of dissolved organic matter export to the coastal zone, results from a spatially explicit, global model. Global Biogeochemical Cycles, 19. doi:10.1029/2005GB002480.

Harrison, J. A., Seitzinger, S. P., Bouwman, A. F., Caraco, N. F., Beusen, A. H. W., \& Vörösmarty, C. J. (2005b). Dissolved inorganic phosphorus export to the coastal zone, results from a spatially explicit. Global model. Global Biogeochemical Cycles. 19. doi:10.1029/2004GB002357.

Hart, B. T., Dok, W. V., \& Djuangsih, N. (2002). Nutrient budget for Saguling reservoir, West Java Indonesia. Water Research, 36, 2152-2160.

He, B., Kanae, S., Oki, T., Hirabayashi, Y., Yamashiki, Y., \& Takara, K. (2011). Assessment of global nitrogen pollution in rivers using an integrated biogeochemical modeling framework. Water Research, $45,2573-2586$. 
Howarth, R. W. (2008). Coastal nitrogen pollution: A review of sources and trends globally and regionally. Harmful Algae, 8, 14-20.

Kamaluddin, R. (2004). Urban poverty in Indonesia: Growth, characteristics and prevention efforts, Seminar on Urban and Regional Development, Department of Economic Development 1 Nov 1-24, Jakarta.

Lasut, M. T., Jensen, K. R., Arai, T., \& Miyazaki, N. (2005). An assessment of water quality along the rivers loading to the Manado Bay, North Sulawesi, Indonesia. Coastal Marine Science, 29(2), 124-132.

Lasut, M. T., Jensen, K. R., \& Shivakoti, G. (2008). Analysis of constraints and potentials for wastewater management in the coastal city of Manado, North Sulawesi, Indonesia. Environmental Management, $88,1141-1150$.

Latifah, S. (2004). Management and control of pollution and marine Coastal. Digital Library, North Sumatra University.

Masrevaniah, A. (2010). Prediction of eutrophication risk caused by N and P containing agriculture waste. International Journal Academic Research, 2, 191-193.

Mayorga, E., Seitzinger, S. P., Harrison, J. A., Dumont, E., Beusen, A. H. W., Bouwman, A. F., et al. (2010). Global nutrient export from watersheds 2 (NEWS 2), Model development and implementation. Environmental Modelling Software, 25(7), 837-853.

Mulholland, P. J., Helton, A. M., Poole, G. C., Hall, R. O, Jr, Hamilton, S. K., Peterson, B. J., et al. (2008). Stream denitrification across biomes and its response to anthropogenic nitrate loading. Nature, 452, 202-205.

Qu, H. J., \& Kroeze, C. (2010). Past and future trends in nutrients export by rivers to the coastal waters of China. Science Total Environment, 408, 2075-2086.

Qu, H. J., \& Kroeze, C. (2012). Nutrient export by rivers to the coastal waters of China: management strategies and future trends. Regional Environmental Change, 12, 153-167.

R. P. A. (Risk and Policy and Annalistic), (2006). Coastal flood risk-Thinking for tomorrow, Acting today. Summary Report, November 2006, ABI.

Rahway, D. (2002). Study of pollution on Karangkates reservoir, Malang. Malang: The Center of Water Resources Development.

Ramu, K. V. P. E. (2004). Brantas river basin case study of Indonesia.

Scheren, P. A., Kroeze, C., Janssen, F. J. J. G., Hordijk, L., \& Ptasinski, K. J. (2004). Integrated water pollution assessment of the Ebrié lagoon, Ivory Coast, West Africa. Journal of Marine Systems, 44, $1-17$.

Seitzinger, S. P., Harrison, J. A., Bohlke, J. K., Bouwman, A. F., Lowrance, R., Peterson, B., et al. (2006). landscapes and waterscapes: a synthesis". Ecological Applications, 16(6), 2064-2090.

Seitzinger, S. P., Harrison, J. A., Dumont, E., Beusen, A. H. W., \& Bouman, A. F. (2005). Sources and delivery of carbon, nitrogen, and phosphorus to the coastal zone: An overview of global nutrient export from watersheds (NEWS) model and their Application. Global Biogeochemical Cycles, 19. doi:10. 1029/2005GB002606.

Seitzinger, S. P., Mayorga, E., Bouwman, A. F., Kroeze, C., Beusen, A. H. W., Billen, G., et al. (2010). Global river nutrient export: a scenario analysis of past and future trends. Global iogeochemical Cycles, 24. doi:10.1029/2009GB003587.

Seitzinger, S. P., Styles, R. V., Boyer, E. W., Alexander, R. B., Billen, G., Howarth, R. W., et al. (2002). Nitrogen retention in rivers: Model development and application to watersheds in the Northeastern USA. Biogeochemistry, 57, 199-237.

Selman, M., Greenhalgh, S., Diaz, R., \& Sugg, Z. (2008). Eutrophication and hypoxia in coastal areas: A Global Assessment of the State of Knowledge. World Resources Institute, Washington, DC. Earth trends: Environmental information. http://earthtrends.wri.org. Washington DC: World Resources Institute.

Standard National Indonesia. (2006). Ecolabelling criteria-Part 2: Category of detergent products, Section 1: Household synthetic washing detergent powder.

Sunarto (2006). Biodiversity and ecosystem degradation of coral reefs. Faculty of Fisheries and Marine Science, Padjadjaran University (Unpublished).

Suwarno, D., Löhr, A., Kroeze, C., \& Widianarko, B. (2013). Past and future trends in nutrient export by nineteen rivers to the coastal waters of Indonesia. Journal of Integrative Environmental Science., 10(1), 55-71. doi:10.1080/1943815X.2013.772902.

Van der Struijk, F., \& Kroeze, C. (2010). Future trends in nutrient export to the coastal waters of South America: implications for occurrence of eutrophication. Global Biogeochemical Cycles. doi:10.1029/ 2009GB003572.

Van Drecht, G., Bouwman, A. F., Harrison, J. A., \& Knoop, J. M. (2009). Global nitrogen and phosphate in urban waste water for the period 1970-2050. Global Biogeochemical Cycles, 23. doi:10.1029/ 2009 GB003458. 
Yan, W., Mayorga, E., Li, X., Seitzinger, S. P., \& Bouwman, A. F. (2010). Increasing anthropogenic nitrogen inputs and riverine DIN exports from the Changjiang River basin under changing, human pressures. Global Biogeochemical Cycles, 24. doi:10.1029/2009GB003575.

Yasin, J. A., Kroeze, C., \& Mayorga, E. (2010). Nutrients export by rivers to the coastal waters of Africa: past and future trends. Global Biogeochemical Cycles, 24. doi:10.1029/2009GB003568.

Yuliastuti, E. T. (2011). River water quality assessment Ngringo Karanganyar in water pollution control efforts. Semarang: Diponegoro University. 